GLOBAL DEVELOPMENT AND ENVIRONMENT INSTITUTE

Working Paper No. 00-08

\title{
Waste in the Inner City: Asset or Assault?
}

Frank Ackerman and Sumreen Mirza

June 2000

Tufts University

Medford MA 02155, USA

http://ase.tufts.edu/gdae 


\title{
Waste In The Inner City: Asset Or Assault? ${ }^{1}$
}

\author{
Frank Ackerman and Sumreen Mirza \\ fackerma@tufts.edu
}

What should low-income neighborhoods do with the one material resource which they possess in abundance - namely, society's wastes? Two opposite answers are at times presented as part of the same strategy of sustainable community development. Some wastes are the basis for a business, adding value to discarded materials. Other wastes are the cause for a crusade, demanding environmental justice for the impacted areas. When does a community view other people's wastes as an asset, and when does it experience waste as an assault?

In an unequal society, there is little mystery about the reasons why undesirable wastes so often end up in the poorest and least powerful communities. Minorities and low-income communities may be just as concerned as anyone else about environmental protection, as suggested by public opinion polls (Ringquist 1999: 235). But their ability to achieve local environmental objectives is limited by their relative position in society. As long as powerful companies and communities seek to externalize their environmental impacts, wastes will end up in remote rural areas and in the least fashionable urban neighborhoods.

This flow of waste, running downhill along the power gradients of society, will continue for the foreseeable future. For better or, often, for worse, it is part of what economists would call the "resource endowment" of low-income communities. While physical and financial capital, most raw materials, and many categories of formally trained or skilled labor are scarce in the inner city, waste is abundant - as are many categories of labor lacking formal training or skills.

Of the two images, waste as an assault on the community is more familiar in discussions of environmental justice. Therefore, we will begin with the unusual notion of waste as an asset.

\section{Cash from Trash}

The sight is a common one in the U.S. "bottle bill" states, where deposits make empty beer and soft drink containers valuable. Someone methodically sifts through public trash cans or curbside recycling bins, pulling out the beverage cans and bottles that can be redeemed for cash. From the perspective of sustainable community development, is this a problem or a solution?

\footnotetext{
${ }^{1}$ An earlier version of this paper was presented at "Towards Sustainability: Social and Environmental Justice", the annual conference of the UK Royal Geographical Society / Planning and Environment Research Group, at Tufts University, June 2000
} 
We can safely ignore the superficial (and generally inaccurate) complaints about litter created or left behind by scavengers. Another possible problem is that removing beer and soft drink containers from recycling bins may deprive municipal recycling programs of much-needed revenue. This concern is genuine but easily exaggerated. Despite the efforts of scavengers, substantial numbers of deposit containers remain in curbside bins and are collected for recycling. A California innovation, crediting recycling programs with the deposits on the estimated number of containers they receive, could eliminate the potential conflict between recycling and deposit laws (Ackerman 1997).

A further problem may speak more directly to what is troubling about scavenging: the fact that some people find it worthwhile to collect bottles and cans out of other people's trash underscores the extraordinary economic inequality of our society. Until we succeed in eliminating that inequality, however, the activities of scavengers will continue - and must be viewed as environmentally beneficial. Beverage container deposit laws, among other effects, direct the energies of some poor people into cleaning up roads, parks, beaches, and other public spaces, and recovering valuable materials for recycling.

In more general terms, waste as an asset is consistent with the free market model of economics. In that model, nations or communities endowed with different resources find it advantageous to produce different products. Low-income areas, so amply "endowed" with waste materials and with low-wage labor, have a comparative advantage in laborintensive processing of materials that the rest of society has discarded.

Imagine a spectrum of environmentally desirable activities, ranked according to the wage rates at which they are profitable. Some are profitable even at high wages, and will therefore occur in the mainstream of the economy. Others are profitable only at low wages, and are therefore available niches that can be filled by workers and businesses from low-income communities.

On a global scale, an extreme example can be seen in the "shipbreaking" industry that recycles big ocean-going ships when they are taken out of service. Some of them, as recorded in the vivid photographs of Sebastino Salgado (1993:200-219), are beached in Bangladesh, where workers using only simple manual tools disassemble them and recover large quantities of scrap metal. Viewed from a society where power tools and machinery are taken for granted, the work appears to be back-breaking and inefficient. Yet if labor is cheap enough and machinery scarce enough, this could be a profitable way to disassemble old ships. Do workers in Bangladesh have better-paid alternatives?

There is a broad range of waste-based occupations, which can be arranged in order of increasing capital and skill requirements. Most are environmentally beneficial; problems occur at the bottom and the top of the range.

Starting at the bottom, the most problematic waste-based occupation, landfill scavenging, is no longer found in the U.S., but is well documented both in American history and in developing countries today. When inequalities are great enough and those at the bottom 
are poor enough, some people will end up working on active landfills in order to glean valuable materials from the freshly dumped waste as it arrives. A Winslow Homer etching from 1859 depicts rag pickers working in a dump in Boston's Back Bay (Rathje and Murphy 1992:14). In the late nineteenth century, when New York City and other coastal communities relied on ocean dumping of garbage, "scow trimmers" rode on the garbage barges, or scows, and continued sorting the refuse up to the last moment (Melosi 1981). The disastrous public health implications of such jobs should be obvious.

Landfill scavenging has vanished from the U.S. today - though in at least one case, it has just barely moved across the border. A study in the twin cities of Laredo, Texas and Nuevo Laredo, Mexico found that many Mexicans make a living collecting aluminum cans on both sides of the border (Medina 1998). Aluminum scavengers working at the landfill in Nuevo Laredo earn more than those on the streets of Laredo, because the much larger waste stream allows them to collect more cans per hour. On average, landfill scavengers earned more than twice the official Mexican minimum wage, while street scavengers earned less than the minimum wage.

When scavenging moves off the landfill and into the streets, incomes may decline but public health is sure to improve. Beyond individual scavenging, there are many small repair businesses and second-hand stores that bring used goods back to life, often selling things that would simply be discarded and replaced in more affluent neighborhoods. There are few environmental problems here, and there are obvious benefits to reusing rather than discarding material goods.

Viewed in a static framework, this point has bleak implications: poverty and inequality lead, in this case, to environmentally desirable behavior that wealthier communities cannot be bothered with. In a dynamic context, the same story can convey a happier message: there are opportunities for environmentally sound economic development that are open to low-income communities.

\section{Building Waste-Based Businesses}

In some cases, environmental advocates have created new waste-based enterprises. Consider one of the numerous businesses that recovers and recycles construction and demolition debris. Garbage Reincarnation, located in Santa Rosa, California, is an organization committed to finding innovative uses for garbage. It has created a "Recycletown" sales yard with buildings constructed out of recycled materials, which are used to sell salvaged building materials such as lumber, wire, and fixtures. Its business arm, Beyond Waste, supplies the recycled materials by deconstructing buildings to maximize reuse of structural components. In a recent job for the City of Hayward, California, Beyond Waste removed a roof of a reservoir building, bidding \$12,000 lower than the nearest competitor, and salvaging about 28,000 board feet, or 50 tons, of old growth Douglas fir (www.garbage.org, www.sonic.net/ precycle). 
The Institute for Local Self-Reliance (ILSR), based in Washington DC, advocates the creation of businesses like Beyond Waste as a cornerstone of community economic development. It has developed a commercial paradigm that goes beyond collection of recyclables by bringing manufacturing into the community to make the finished product. Working with city governments, community organizations, and private businesses it has helped to establish more than 15 recycling based businesses with over 250 employees and \$20 million in new investment in low income and working class communities. ILSR has worked in Washington, Baltimore, Cleveland, Philadelphia, Gary, Evansville, Chattanooga, and Los Angeles, establishing recycling programs where none existed, and then building partnerships to establish sound businesses that provide jobs and investment in the urban core (www.ilsr.org).

Not all waste-based businesses are created by environmentalists. Scrap yards have traditionally recycled large quantities of steel and other metals. Every year, millions of cars and appliances reach the end of their useful life, yet comparatively few of them end up rusting on roadsides, in fields and yards, or in landfills. In fact, scrap yards recycled more than 13 million cars and 39 million appliances in 1999, achieving recycling rates of $91 \%$ for cars and $77 \%$ for appliances - far above curbside recycling rates (www.recyclesteel.org).

As the example of scrap yards suggests, there is no sharp line between waste-based businesses and the industrial economy as a whole. Indeed, scrap processors have become sophisticated, complex manufacturing facilities capable of preparing and grading huge quantities of inventory to the specifications of industrial consumers. The EPA's Jobs Through Recycling program estimates that industries related to recycling create one million manufacturing jobs and $\$ 100$ billion in revenue.

A final example, at the interface between waste-based community development and large-scale industry, reveals both the promise and the problems of recycling enterprises.

Recycling facilities may seem like innovative economic tools for community advancement, as in the well-publicized proposal for a paper recycling plant in the Bronx. But despite community involvement, sensitivity to local needs, and careful planning, such ideas can inadvertently become an additional burden on the community. In 1992, the Natural Resources Defense Council teamed up with a Bronx community development corporation, Banana Kelly Civic Improvement Association, to bring a paper recycling facility to the South Bronx. This partnership was designed to demonstrate that the environmental movement was sensitive to the needs of low-income communities, and to create an environmentally friendly paper making facility in an area that has suffered from the loss of blue-collar jobs.

The plant was intended to use the cleanest technology to recycle office waste paper from $\mathrm{NYC}$ and make high-grade paper for newspapers and magazines. It was met with community opposition because the facility would increase air pollution in an already burdened community, and because many people viewed the project as a waste transfer station disguised as economic development (Colon 1999). The jobs it provided would 
have been limited and low-skilled. As environmental justice advocates rightfully assert, communities should not have to be poisoned to get economic improvements; and no amount of money can buy self-respect. Ultimately, the conflict with the community, as well as the low and fluctuating price of recycled paper, contributed to the cancellation of the project (see Forero 2000 on cancellation, and Ackerman and Gallagher 2000 on the price of recycled paper).

\section{Rounding Up The Usual Suspects}

Consider, then, the alternative perspective, of waste as an assault on a low-income community. (It is presented more briefly here, not because it is less important, but because it is more familiar.) Waste pollutes the neighborhood, contaminates the water, fouls the air, clogs the streets with garbage trucks, and lowers property values. Toxic materials, sometimes dumped illegally to avoid legitimate disposal costs, create acute local health hazards. Even "legitimate" disposal of hazardous waste in the inner city can both degrade the physical environment and worsen public health. The working poor are more likely to be unprotected by health care insurance, to suffer more from toxicinduced-or aggravated diseases, and to spend higher proportions of their income on medical and health care as compared with more affluent groups.

Disposal of hazardous waste does not create economic development or waste-based businesses that benefit the host neighborhood. Instead, it is universally seen as an assault on the community, and frequently results in a legal challenge. Communities have resorted to a variety of rules and tools at their disposal, and, in a number of cases, have succeeded in blocking unwanted facilities.

Charges of environmental racism have been particularly effective, highlighting the far from random distribution of the least desirable facilities. In fact, it was protest against a toxic waste landfill in a predominantly African American community in Warren County, North Carolina that galvanized the environmental justice movement in 1982. Although the community was unable to prevent the landfill from opening, it gained media attention from the imprisonment of over 400 protestors. The problem was not unique to that county: a 1987 report commissioned by the United Church of Christ, entitled "Toxic Wastes and Race," found that race was the most prominent factor in determining the location of a commercial hazardous waste facility (Sandweiss 1998).

Inner city communities across the country have toxic waste sites in their backyards. South Central Los Angeles, a 1-square mile area saturated with abandoned toxic waste sites, freeways, smokestacks, and wastewater pipes, has been described as the dirtiest zip code (90058) in California (Bullard 1993). In South Chicago, Illinois, state officials became more receptive to the residents' complaints when during an inspection of one noxious waste lagoon, the boat carrying the state environmental inspectors began to disintegrate beneath them (Ringquist 1999).

While the environmental justice movement continues to oppose discriminatory facilities it is also employing the precautionary principle to prevent further degradation from 
occurring. This shift is embodied in the Ten Principles of Environmental Justice established at the People of Color Leadership Summit on the Environment in Washington, D.C. in 1991. Furthermore, President Clinton's Executive Order 12898 passed in February 1994 also addresses environmental discrimination, though it is more a covenant than a legally binding document. Finally the environmental justice movement has also helped establish the National Environmental Justice Advisory Council.

In addition to these national milestones, local progress is being made as well. New York City has developed a "fair share" model, to ensure that each of the five boroughs bears its fair share of noxious facilities. Chicago now assesses the demographic makeup of proposed host neighborhoods for waste sites, and evaluates the cumulative impact a new facility would have on existing environmental burdens (Bullard 1993). But it remains to be seen how these policies will work in practice.

\section{What's the Difference?}

In discussing waste as an assault on inner city communities, we have entered a different realm of environmental discourse, the world of Woburn and Love Canal, of Bhopal and Erin Brockovich. No one, hopefully, scavenges hazardous waste for a living. No one sensibly proposes that toxic-waste-based businesses are part of an economic development strategy. Indeed, a comprehensive strategy for sustainable community development must distinguish between wastes that are assets and wastes that are assaults, between wastebased opportunities and waste-related dangers.

What accounts for the difference between these two faces of waste? Most obviously, things described as waste vary immensely in toxicity. Some are intensely hazardous and should only be handled with sophisticated technical precautions and protections; others can reasonably be seen as merely ugly resources waiting to be exploited. Unfortunately, the identification of hazardous wastes, and hence the separation of wastes into these two categories, can itself be a task requiring technical expertise. Familiar categories of municipal waste and construction debris are generally safe to handle with modest precautions; but no such presumption can be made about chemical wastes and other industrial byproducts.

A subtler distinction can also be drawn. Most of the hazards associated with waste in the inner city are caused by processing and disposal facilities. The chemical transformations that occur in these facilities may create new hazards, in addition to any that were present in the incoming feedstock. In contrast, many of the benign opportunities for waste-based occupations and businesses involve only sorting, repair, assembly/disassembly, and similar processes that cause minimal emissions. When waste-based businesses reach a level of material processing that generates significant emissions, as with the proposed South Bronx recycled paper mill, they too face community opposition.

In conclusion, there are three waste-related requirements for sustainable community development. First, it is important to identify hazardous wastes and processes, and to 
insist on regulation that prevents them from harming residential neighborhoods. The environmental justice movement rightly objects that hazards are disproportionately located in poor and minority areas; many of these hazards should not be located anywhere, but should be replaced by cleaner, safer, materials and processes. Second, waste-based enterprises with significant emissions, such as recycled paper mills, should generally not be located in residential areas, and should be subject to the same pollution controls as other industries. Finally, low-income communities should welcome the opportunity to create low-emission businesses and jobs based on the nonhazardous wastes which they so often possess in abundance.

Frank Ackerman is Director of the Research and Policy Program of the Global Development And Environment Institute and Research Associate Professor at Tufts University's Urban and Environmental Policy and Planning Program.

Sumreen Mirza is a graduate student at the Department of Urban and Environmental Policy and Planning at Tufts University.

\section{REFERENCES}

Ackerman, Frank. Why Do We Recycle? Markets, Values, and Public Policy, Island Press, 1997.

--, and Kevin Gallagher, "Mixed Signals: Recycling, Price Incentives, and the Crisis of 1995”, working paper, Tufts University, 2000.

Bullard, R. "Environmental Justice for All," in Bullard (ed) Unequal Protection. San Francisco, Sierra Club Books, 1993, pg. 3-22.

Colon, Melvyn. "The Bronx Community Paper Company," Tufts University, 1999, based on Eric Weltman, "Recycling in the South Bronx: Unintended Lessons", Tufts University masters thesis, 1996, and other sources.

Forero, Juan, "Plans to Build Paper Recycler In South Bronx Are Called Off", New York Times, July 21, 2000, p.B7.

Medina, Martin. "Border Scavenging: A Case Study Of Aluminum Recycling In Laredo, Texas, and Nuevo Laredo, Mexico," Resources, Conservation, and Recycling, Vol. 23, no. 3, 1998, pgl. 107-126.

Melosi, Martin. Garbage in the Cities: Refuse, Reform, and the Environment, 18801980. College Station, TX, Texas A\&M University Press, 1981.

Rathje, William, and Cullen Murphy. Rubbish! The Archaeology of Garbage, New York, HarperCollins, 1992. 
Ringquist, Evan. "Environmental Justice: concerns and empirical evidence," in Vig, NY and Kraft, ME , Environmental Policy, (Fourth Edition). Washington, DC, Island Press, 1999, pg. 232-256.

Salgado, Sebastino. Workers: An Archaeology of the Industrial Age, New York, Aperture Press, 1993.

Sandweiss, S. "The social construction of environmental justice," in Camacho, D (ed), Environmental Injustices, Political Struggles. Durham, Duke University Press, 1998, pg. 31-57. 
The Global Development And Environment Institute (G-DAE) is a research institute at Tufts University dedicated to promoting a better understanding of how societies can pursue their economic goals in an environmentally and socially sustainable manner. G-DAE pursues its mission through original research, policy work, publication projects, curriculum development, conferences, and other activities. The "G-DAE Working Papers" series presents substantive work-in-progress by G-DAE-affiliated researchers. We welcome your comments, either by e-mail directly to the author or to G-DAE, Cabot Center, Fletcher School, Tufts University, Medford, MA 02155 USA; tel: 617-627-3530; fax: 617-627-2409; e-mail: gdae@tufts.edu; web: http://ase.tufts.edu/gdae.

\section{Papers in this Series:}

00-01 Still Dead After All These Years: Interpreting the Failure of General Equilibrium Theory (Frank Ackerman, November 1999)

00-02 Economics in Context: The Need for a New Textbook (Neva R. Goodwin, Oleg I. Ananyin, Frank Ackerman and Thomas E. Weisskopf, February 1997)

00-03 Trade Liberalization and Pollution Intensive Industries in Developing Countries: A Partial Equilibrium Approach (Kevin Gallagher and Frank Ackerman, January 2000)

00-04 Basic Principles of Sustainable Development (Jonathan M. Harris, June 2000)

00-05 Getting the Prices Wrong: The Limits of Market-Based Environmental Policy (Frank Ackerman and Kevin Gallagher, September 2000)

00-06 Telling Other Stories: Heterodox Critiques of Neoclassical Micro Principles Texts (Steve Cohn, August 2000)

00-07 Trade Liberalization and Industrial Pollution in Mexico: Lessons for the FTAA (Kevin Gallagher, October 2000) 